\title{
Global Warming, Glacier Melt \& Sea Level Rise: New Perspectives
}

\author{
Madhav L Khandekar \\ Climate Scientist, Markham Ontario \\ Canada
}

\section{Introduction}

There is a heightened interest at present on the possibility of rapid melting of world-wide glaciers and ice caps (e.g., Greenland \& Antarctic Ice Caps) as a result of ongoing global warming, which could lead to escalated sea level rise in future. Several stories and news items in the print \& TV media and also in scientific magazines seem to strongly suggest that glaciers and ice caps are melting faster than ever and this could lead to significant rise in global and regional sea level. Recent popular Hollywood movies like An Inconvenient Truth showing big ice shelves breaking off and sliding down into cold Arctic Ocean seem to reinforce this perception that the ice caps and glaciers are indeed melting rapidly and causing sea level to rise dramatically. From a scientific perspective, satellite altimeter data (Topex/Poseidon) have estimated recent sea level rise of about $3 \mathrm{~mm} / \mathrm{yr}$ and possibly higher, this value being significantly higher than the traditionally held value of about 1.5 to $2 \mathrm{~mm}$ per yr (for most of the twentieth century) has generated sufficient interest among the scientific community about 'escalating sea level rise' in near future. In a recent (Journal of Climate 2007) paper, the lead author Prof (Emeritus) Carl Wunsch states that "Modern sea level is a matter of urgent concern from a variety of points of view, but especially because of possibility of its acceleration and consequent threats to many low-lying parts of the inhabited world ". The Intergovernmental Panel on Climate Change (IPCC), a UN Body of scientists, has been making periodic review of the earth's climate change since 1990. In its most recent climate change documents (Meehl 2007), the IPCC projects global sea level rise (SLR) for the next 100 years to be between 14 and $43 \mathrm{~cm}$ ( with a mean value of $29 \mathrm{~cm}$ ) under an emission scenario A1B ( these emission scenarios have been developed using economic development indices for world countries) in which the earth's mean temperature is projected to rise between 2.3C and 4.1C by 2100. The IPCC projects largest increase in SLR (about $230 \mathrm{~mm}$ by 2100) as due to thermal contribution, resulting from warming of the earth's surface and associated expansion of water in future. The contribution due to melting of glaciers and ice caps is estimated by the IPCC to be about $60 \mathrm{~mm}$ over next 100 years. These two components namely thermal (or steric) and mass balance (or eustatic) are being closely examined at present in the context of several recent studies on climate sensitivity and observational evidence of increased glacier melting.

In this chapter, a brief background of the global warming science is presented in section 2 . This is followed by a discussion on sea level rise over the past several thousand years and 
the present state of SLR as determined by world-wide sea level records like tide gauge and modern satellite altimetry. The impact of recent warming on global \& regional SLR by way of glacier melt (eustaic rise) and thermal expansion (steric rise) is discussed in the context of observational and other theoretical studies as well as several uncertainties associated with some of the estimates. Also discussed is the present state of sea level change at some of the most vulnerable areas like The Maldives in the equatorial Indian Ocean and the Tuvalu Island in the south Pacific. An estimate of present and future SLR is obtained using most recent studies and the possibility of escalated sea level rise at selected locations is analyzed.

\section{A brief overview of the global warming science}

The present debate on the global warming science may have begun with a landmark paper (Revelle \& Suess 1958) in which the lead author, (late) Roger Revelle, an eminent geophysicist, suggested that humans are carrying out a large-scale geophysical experiment through world-wide industrial activity that could lead to the build-up of $\mathrm{CO}_{2}$ greater than the rate of $\mathrm{CO}_{2}$ production by volcanoes. Revelle \& Suess estimated human-added $\mathrm{CO}_{2}$ in the earth's atmosphere and expressed concern that this continued build-up of carbon dioxide by human activity could impact earth's climate in future through absorption of long-wave radiation emanating from the earth's surface. Revelle was instrumental in establishing the first carbon-dioxide measuring station at Mauna Loa, Hawaii in 1956. Another carbondioxide measuring station was later established in the Antarctic and at present there are several dozen locations providing carbon-dioxide measurements world-wide. Based on these measurements it is now well established that the concentration of atmospheric carbon dioxide, the principal greenhouse gas, has increased from about $350 \mathrm{ppmv}$ (parts per million by volume) in 1956 to about 385 ppmv today. Besides carbon dioxide, there are two other atmospheric gases namely methane $\left(\mathrm{CH}_{4}\right)$ and nitrous oxide $\left(\mathrm{N}_{2} \mathrm{O}\right)$ which are also considered as 'greenhouse gases' whose concentration in the earth's atmosphere is much smaller than carbon dioxide. It should be noted here that the earth's atmosphere consists of nitrogen $(\sim 78 \%)$, oxygen $(\sim 21 \%)$ and argon $(\sim 0.93 \%)$, while carbon dioxide makes up for just about $0.03 \%$ of total atmospheric gases. It should be also noted that atmosphere-ocean system is continuously exchanging carbon dioxide which is estimated at about 150 billion tons (Giga-tons OR Gt) annually, while the human-added $\mathrm{CO}_{2}$ is about 20-22 billion tons annually, just about $15 \%$ of total carbon dioxide exchange between atmosphere and ocean.

The publication of Revelle/Suess paper sparked rapid development of a number of computer-based climate models which attempted to simulate the impact of increasing future carbon-dioxide concentration on the earth's mean temperature. Using steadily increasing concentration of carbon dioxide based on some assumed emission scenarios, some of the climate models developed in the 1980s and 1990s have projected mean temperature increase of $3 \mathrm{C}$ to $6 \mathrm{C}$ or more, by the end of 2100. A recent study (Knutti et al 2008) examines a suite of state-of-the-art climate models and associated uncertainties. This study (by Knutti et al) obtains a best guess value of $2.8 \mathrm{C}$ with a range of $1.7 \mathrm{C}$ to $4.4 \mathrm{C}$ for mean temperature increase by 2100 . Many climate models now estimate the mean temperature increase for a doubling of the present value of carbon dioxide concentration (e.g, from a present value of 350 to value say 700 or about) over next fifty to one hundred years and this value is often referred to as climate sensitivity. Several recent studies (e.g., Lindzen 2007; Schwartz 2007; 
Chylek \& Lohmann 2008) now suggest that the climate sensitivity obtained by most climate models is too large and a more realistic value seems to be just about $1 \mathrm{C}$ to $1.2 \mathrm{C}$. Whether the earth's mean temperature warms by as much as 3C or more by 2100 is one of the most contentious issues in the global warming science today.

The evolution of the earth's mean surface temperature over the last 150 years is shown in Figure 1. This mean temperature graph is obtained by calculating for each year, a mean value using all available land station data which are suitably combined with Sea Surface Temperature (SST) data to come up with one single value for each year. Such calculations are subject to contamination due to urbanization impact, large-scale circulation changes etc, as discussed in Khandekar et al (2005) and many other recent papers. Despite such uncertainties in mean temperature calculation, Figure 1 does provide a general representation of the earth's mean temperature evolution over last 150 years. The temperature curve shows two distinct periods of warming, one from 1910-1945 and the recent warming from about 1977 till present. It may also be noted that from 1945 till about 1977, the earth's mean temperature declined by about $0.25 \mathrm{C}$. The year 1998 has been designated as the 'hottest year' according to the IPCC benchmarks. In Figure 2 global mean temperature trends for the recent years (since 2002) are shown together with atmospheric carbon dioxide trend. Note that the carbon dioxide concentration is increasing while global mean temperature is steadily declining in the last seven years or about. This has become another contentious issue in the present global warming debate.

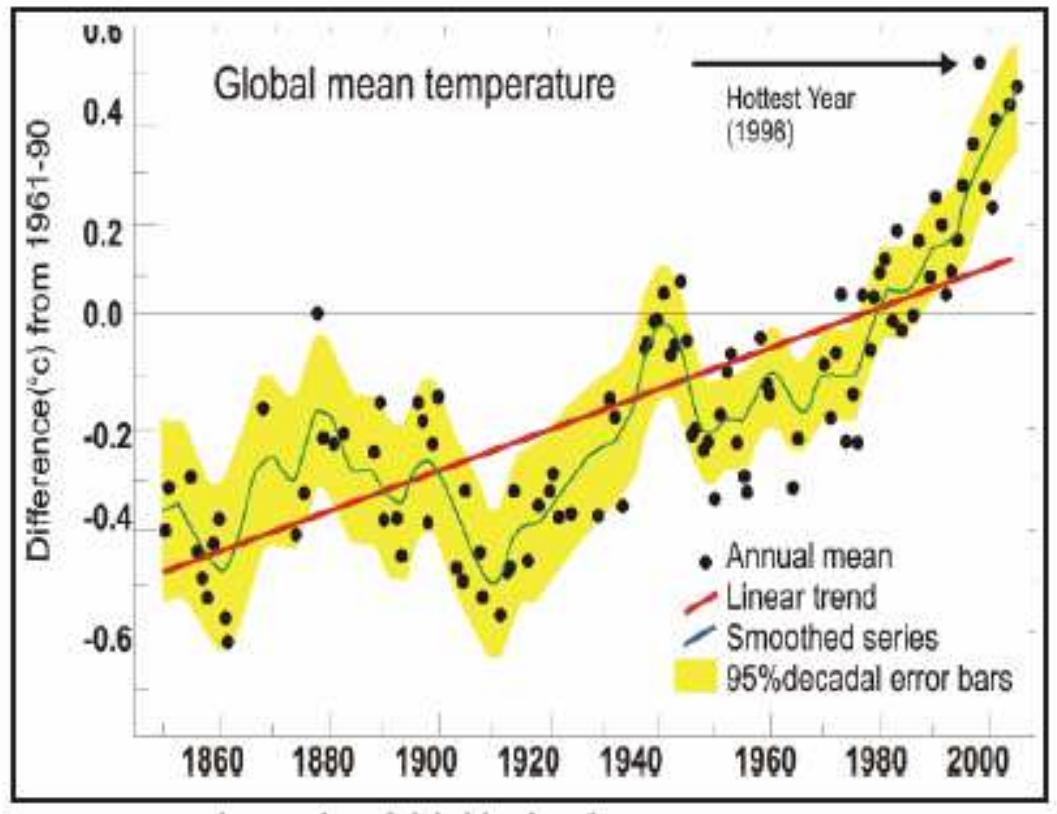

Fig. 1. Global mean temperature anomalies, 1860-2005 (IPCC 2007)

The temperature anomalies are calculated with respect to base period 1960-1990. 


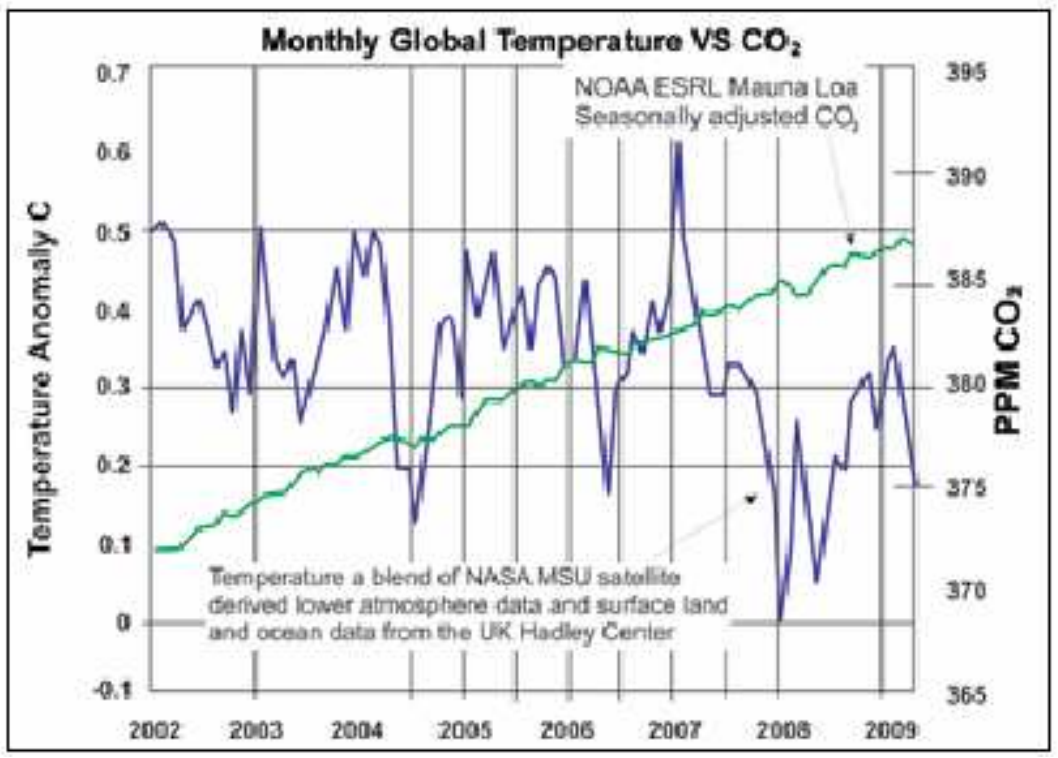

Fig. 2. Global mean temperature variation since 2002, together with variation of atmospheric carbon dioxide (parts per million, by volume).

\section{Sea level rise, past \& present}

It is now generally accepted that since the Last Glacial Maximum (LGM) $21000 \mathrm{yr}$ BP (Before Present), the sea level has risen by about $120 \mathrm{~m}$. Most of this rise occurred as the vast amounts of ice sheets and ice caps in northern and Arctic latitudes started to melt as the earth's mean temperature steadily warmed. The melting of the high-latitude ice mass was essentially completed by about 5000-6000 yr BP (Douglas \& Peltier 2002). Thereafter, global sea level rise was very small and appears to have ceased by 3 to 4 thousand yr BP. The rate of SLR over the last 1000 years and prior to the twentieth century is estimated to be just about $0.2 \mathrm{~mm} / \mathrm{yr}$ (Fleming et al 1998; Lambeck 2002). The sea level rise in the late twentieth century is most intriguing and has sparked a large number of studies in the last decade (Douglas \& Peltier 2002; Munk 2002; Church et al 2004; Holgate \& Woodworth 2004; Jevrejeva et al 2006; Holgate 2007). These and many other studies provide following general assessment for the twentieth century sea level rise: a. The rate of sea level rise was larger in the first half of the $20^{\text {th }}$ century $(2.03 \mathrm{~mm} / \mathrm{yr})$ than in the second half $(1.45 \mathrm{~mm} / \mathrm{yr})$. $\mathbf{b}$. There is evidence of 2-13 yr variability in sea level records increasing during the last fifty years over most ocean basins. c. Among major sources of uncertainty are; inadequate distribution of tide gauges particularly in the southern hemisphere, inadequate information on geophysical signatures (e.g. glacial isostatic adjustment \& tectonic activity) and relatively short duration of satellite altimetric data for the latter half of $20^{\text {th }}$ century.

The GIA (Glacial Isostatic Adjustment) refers to the gradual springing back of the earth's surface, especially in the higher latitudes, in response to the removal of ice loads of the LGM which were at their maximum extent around $21000 \mathrm{yr}$ BP. The GIA is still significant in the region around the Gulf of Bothnia (often referred to as Fennoscandia) which was covered 
with ice to a depth of several kilometers during the LGM and where relative sea level is currently falling at the rate of $5-10 \mathrm{~mm} / \mathrm{yr}$ as the land in that region continues to rebound. The issue of GIA is well articulated by Prof R Peltier (University of Toronto Canada) and his associates in a series of papers (Peltier 1996, 1998, 2001). A recent paper (Peltier 2009) obtains revised estimates of sea level rise due to glacier melts using the GRACE (Gravity Recovery \& Climate Experiment) data from a special satellite launched in March 2002. The GRACE Data provide finer estimates of glacier melt contribution against the backdrop of post-glacial rebound of the earth's surface; these estimates will be discussed later.

\section{How fast are glaciers melting?}

This has become an intensely debated topic in the global warming science today. Several media reports of rapid melting of polar glaciers and news items about ice shelves of various sizes and magnitude breaking away and sliding into polar oceans have crated a heightened interest about escalated sea level rise in the next decade or more. This issue also appears to have generated considerable interest in the scientific community with a number of papers, articles \& scientific commentaries appearing in recent literature (e.g., Munk 2003; Cazenave 2006; Meier et al 2007; Mitrovica et al 2009; Bahr et al 2009). These and many other recent papers now strongly suggest increased melting of high-latitude glaciers in the last ten years and this is leading to substantially increased contribution to the total sea level rise. Further, it is now speculated that this glacier mass contribution would be accelerating in the next few decades leading to much higher value of SLR than what the IPCC has projected in its 2007 Climate Change Documents. In an Associated Press (AP) news item dated 25 February 2009, Colin Summerhayes, executive director of the UK-based Committee on Antarctic Research suggested that glaciers in Antarctica are melting faster than previously thought and such accelerated melting could cause sea levels to climb by 3 to 5 feet $(\sim 75 \mathrm{~cm}$ to $130 \mathrm{~cm})$ by the end of the twenty-first century. In a scientific commentary by Meier et al (2007), the authors conclude that contribution by small glaciers (other than two ice caps, Greenland and Antarctic) has accelerated over the past decade and this accelerated melting could cause 0.1 to $0.25 \mathrm{~m}$ of additional sea level rise by 2100. In another recent paper, the authors (Bahr et al 2009) conclude that if the climate continues to warm along current trends, a minimum of $373+/-21 \mathrm{~mm}$ of sea level rise over next 100 years is expected from glaciers and ice caps.

The idea that 'world-wide glaciers and ice caps are melting faster than before' seems to be gaining traction among the scientific community. What is however, not clear at this point in time is: how fast is sea level rising, at global and/or regional level? Studies reported in recent literature using the satellite-based altimeter data (known as Topex/Poseidon) suggest the sea level rise between 2.8 to $3.2 \mathrm{~mm}$ /year, but other studies using tide gauge data or a combination satellite and tide gauge data show a significantly smaller value. In a recent paper, Holgate (2007) analyzed nine long and nearly continuous sea level records over one hundred years (1903-2003) and obtained a mean value of SLR as $1.74 \mathrm{~mm} / \mathrm{yr}$ with higher rates of sea level rise in the early part of twentieth century compared to the latter part. Figure 3 shows cumulative sea level rise through the twentieth century as obtained by Holgate. In a most comprehensive recent study, Wunsch et al (2007) generate over 100 million data points using a 23-layer general circulation model with a $1^{0}$ horizontal resolution. The general circulation model uses different types of observed data, like ocean salinity, sea surface temperature, satellite altimetry and Argo float profiles over a period 1993-2004. Based on careful analysis of such a large database, the authors (Wunsch et al) 
obtain a global mean value of SLR as $1.6 \mathrm{~mm}$ /year for the period 1993-2004. The authors also identify several uncertainties and regional variations in the altimetric data and conclude that "it remains possible that the database is insufficient to compute sea level trends with the accuracy necessary to discuss the impact of global warming - as disappointing as the this conclusion may be"

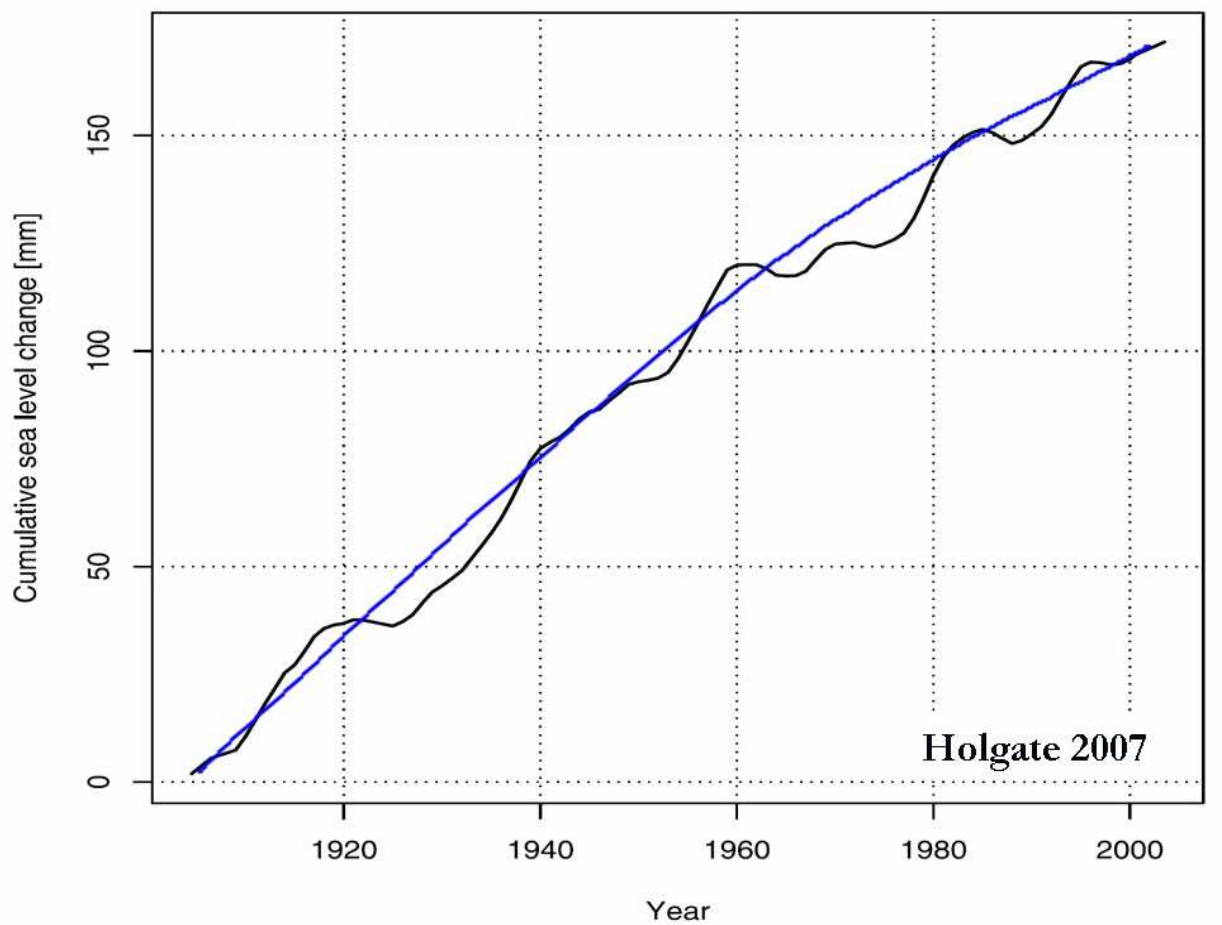

Fig. 3. Cumulative sea level rise 1900-2003. The total sea level rise in the first half of twentieth century was about $10 \mathrm{~cm}$, while for the latter half the rise was about $7 \mathrm{~cm}$. (Holgate 2007)

\section{Sea level rise using GRACE data}

As mentioned earlier, the GRACE (Gravity Recovery \& Climate Experiment) satellite launched in March 2002 has provided valuable data so far on the rate of mass loss from polar ice sheets and also on the post-glacial rebound of the earth's surface. The GRACE data appear to provide confirmation of the ongoing glacial rebound of the North American Continent caused by deglaciation of the Laurentide, Innuition and Cordilleran ice sheets that began about 21000 yr BP. (Paulson et al 2007; Peltier \& Drummond 2008). Such a confirmation allows an improved estimate of sea level rise by removing GIA contamination of sea level rise due to recent glacial melts. Two important recent papers, one by Cazenave et al (2008) and the other by Peltier (2009) have provided useful estimates of sea level changes due to various processes. These findings of Cazenave et al \& Peltier can be summarized as follows: 
From 2003 to 2008, the total ocean mass contribution to sea level rise is now estimated as about $2.27 \mathrm{~mm} / \mathrm{yr}$. Of this, the contribution from the two ice sheets (Greenland and Antarctica) is estimated at about $1.0 \mathrm{~mm} / \mathrm{yr}$, while the contribution from remaining (small) glaciers and ice caps is estimated at about $1.1 \mathrm{~mm} / \mathrm{yr}$; additional contribution of about 0.17 $\mathrm{mm} / \mathrm{yr}$ is from land waters due to future desiccation (of land areas). The thermal contribution is estimated as the difference between satellite altimteric sea level and the GRACE-based ocean mass component and comes out to be about $0.37 \mathrm{~mm} / \mathrm{yr}$. The total sea level rise in the most recent period 2003-2008, is now estimated to be about between 2.5 to $2.65 \mathrm{~mm} / \mathrm{yr}$, which is less than the satellite altimetric value of $3.1 \mathrm{~mm} / \mathrm{yr}$. Cazenave et al further observe that the thermal contribution during the 1993-2003 period was estimated to be about $1.2 \mathrm{~mm} / \mathrm{yr}$ which has now declined to just about $0.37 \mathrm{~mm} / \mathrm{yr}$ in the most recent period 2003-2008. Once again, the glacier (and ice cap) melting is identified as the dominant contributor to the present sea level rise, while the thermal contribution appears to have declined, possibly in response to declining sea surface temperatures (SST) in the last five years. This aspect of sea level rise and its linkage to temperature change of the $20^{\text {th }}$ century is discussed below.

\section{Sea level rise in the context of $20^{\text {th }}$ century temperature change:}

The earth's temperature history for the twentieth century ( Figure 1) shows two warming periods, one during the early part of the twentieth century (1910-1945) and the second since about 1977 till 1998, after which the mean temperature appears to have 'leveled off'. It is also instructive to note that there was a distinct period of cooling 1945-1977, when the earth's mean temperature declined by about $0.25 \mathrm{C}$. The sea level variation during the twentieth century is most enigmatic and deserves a careful assessment. According to Holgate (2007), the total rise was about $17 \mathrm{~cm}$ (see Figure 3) with higher rise $(\sim 10 \mathrm{~cm})$ during the first half and lower rise $(\sim 7 \mathrm{~cm})$ during the second half of the $20^{\text {th }}$ century. The decadal rise in sea level as shown in Figure 4 reveals interesting variations with lowest decadal rise (-1-49 $\mathrm{mm} / \mathrm{yr}$ ) centered on 1964, while the highest rise is centered on 1980 (5.31 mm/yr). The latter part of Figure 4 suggests increasing rates of sea level rise, with larger fluctuations of low and high values. Can these decadal variations be linked to land-ocean temperature changes of the last thirty years?

Let us consider global SST variations as shown in Figure 5. Here the global SST anomalies (with respect to a mean value for the $20^{\text {th }}$ century) are plotted as 12-month moving averages and the SSTs appear to be increasing since 1980, reaching a peak value by early 1998 . This peak SST value on a global scale is most certainly linked to the intense El Nino event of 1997/98 which helped raise SST over other ocean basins as well (see Arun Kumar et al 2001). The global SSTs have declined rather sharply since the peak of 1998 and this may help explain a significant decline in the thermal contribution to sea level rise during the last five years in particular. Future sea level rise due to thermal expansion (steric component) is expected to be smaller in view of low climate sensitivity values obtained in several recent studies.

The warming of the earth's climate during the early part of twentieth century (1910-1945) and its possible impact on glacier melt appears to have been neglected in the present debate, by the media and by the scientific community as well. A close look at Figure 1 shows that the earlier warming (1910-1945) was quite steep from about 1920 to 1935, especially in the Arctic region. According to Chylek et al (2005), the Arctic warmed at a faster rate during 


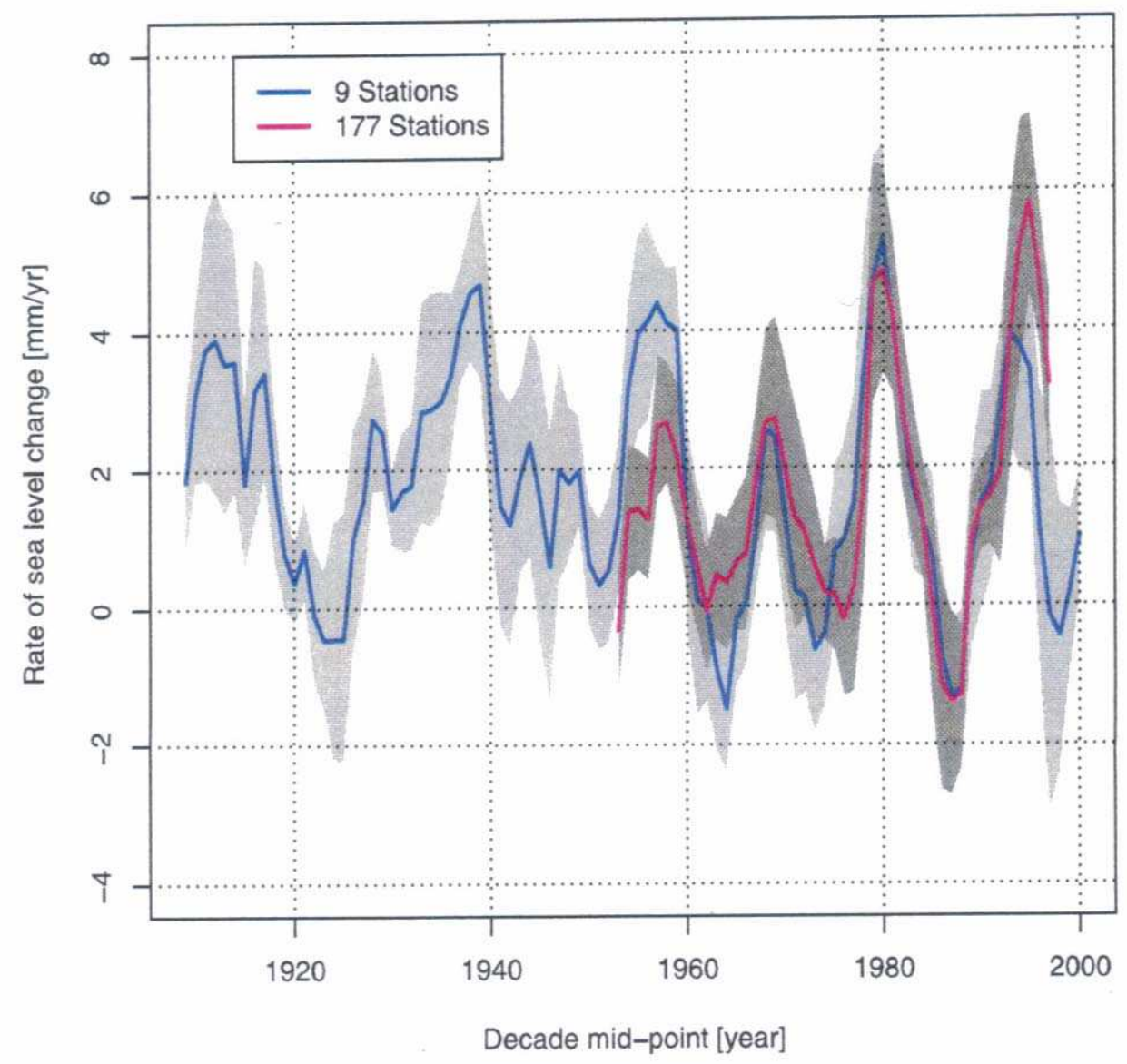

Fig. 4. Global mean decadal rates of sea level changes based on nine long tide gauge records (blue), compared with rates from 177 stations (red). All rates are corrected for glacial isostatic adjustment and inverse barometric effects. Shaded region indicates $+/-1$ standard error (from Holgate 2007)

1920-1930 than it did during 1995-2005 and in the early part of the new millennium. According to Dr Igor Polyakov of the University of Alaska USA, who has collected an excellent set of data for the Arctic Basin from 1860 till present, the Arctic Basin was at its warmest in 1935 and 1936. In another recent study, Vinther et al (2006) have extended Greenland temperature records to 1874 using long-term temperature data available with the Danish Meteorological Institute. Vinther et al show that the decade 1930s and the 1940s were the warmest decades in Greenland and 1941 was the warmest year in Greenland in the 135-year temperature data of Greenland. 


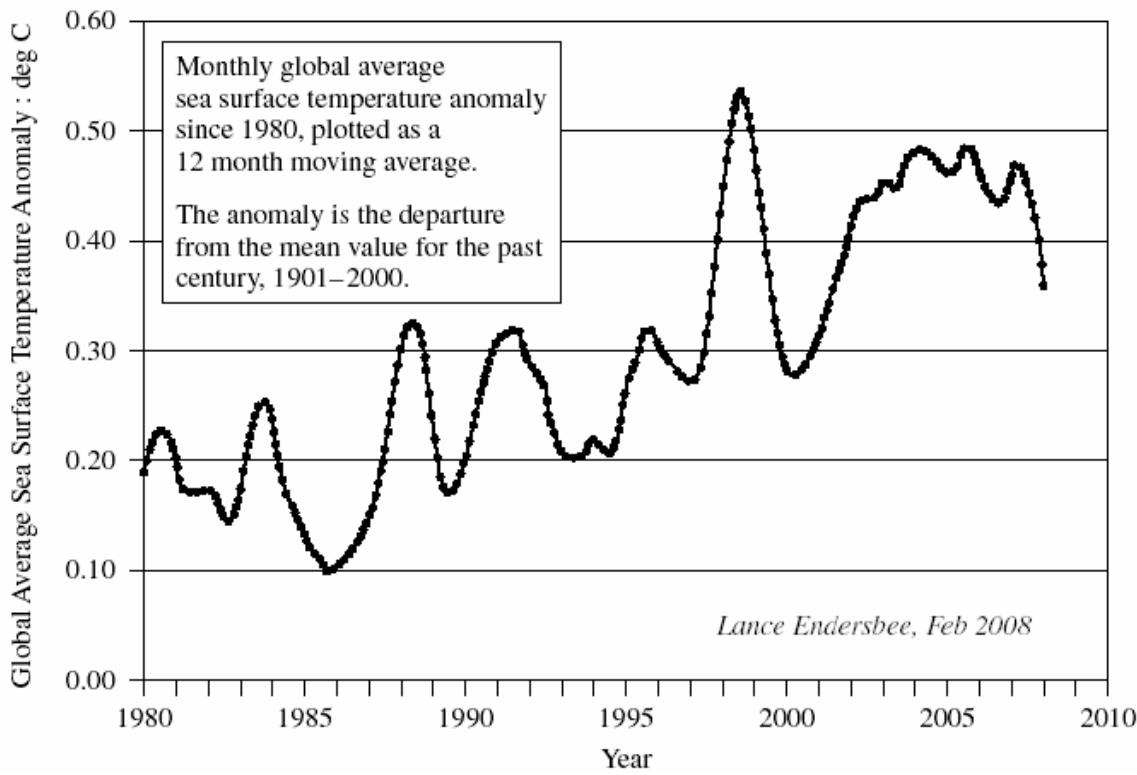

Fig. 5. Global average sea surface temperature anomalies plotted as a 12-month moving average. (Source: (late) Prof Lance Endersbee, Australia)

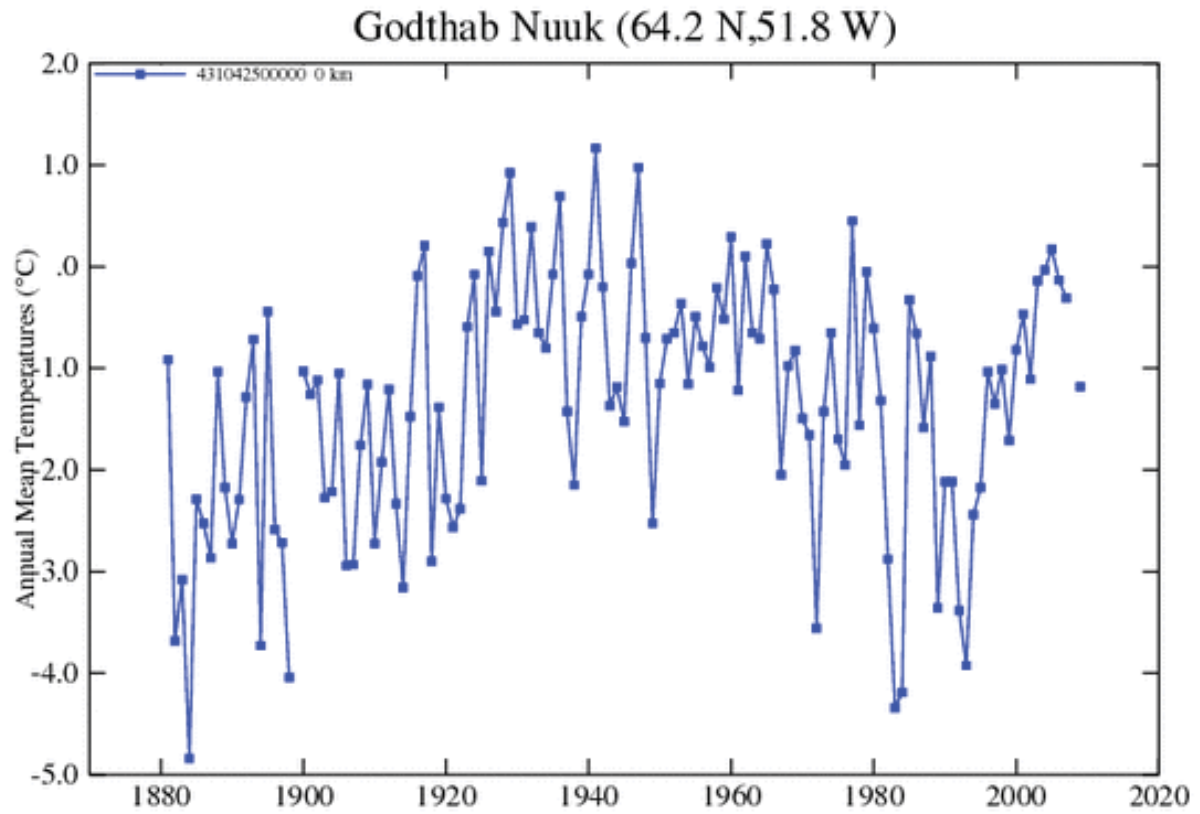

Fig. 6. Mean surface temperature history for Greenland 1880-2007. Note the highest temperature in 1941. 
Figure 6 shows the temperature history of Greenland from 1860 and reveals clearly how Greenland was at its warmest in 1941. Since then Greenland temperature has declined till about 1980 and has climbed up to about the same level it was in 1941. A scientific commentary on the Arctic conditions in the 1920s reads: "The Arctic Ocean is warming up, icebergs are growing scarcer and in some places the seals are finding the water too hot. Reports all point to a radical change in climate conditions and hitherto unheard of temperatures in the Arctic zone. Great masses of ice have been replaced by morains of earth and stones, while at many points well-known glaciers have entirely disappeared" (US Weather Bureau 1922).

It is obvious from above that significant glacier and ice cap melting was going on in the Arctic during the 1920s and the 1930s. However, no satellite or other remote-sensed technology was available to obtain reliable estimates of glacier melts and rates of melting during the period 1920-1940, when most of the Artic was very warm and Greenland witnessed perhaps the 'hottest climate' in a 150-year instrumented temperature data. The impact of glacier melts of the 1920s and 1930s on subsequent sea level rise can be assessed by noting that total sea level rise since 1940 till 2008 is about $12 \mathrm{~cm}$. Of this total rise, only about $8 \mathrm{~cm}(80 \mathrm{~mm})$ can be attributed to glacier melt while the remaining is attributable to thermal expansion of water. Using this argument, we can estimate present glacier melt contribution to future sea level rise as about $12 \mathrm{~cm}$ or about $120 \mathrm{~mm}$ at most, in the next 100 years or so. This estimate is significantly less than the estimate obtained in some of the recent studies (e.g., Meier et al 2007; Bahr et al 2009). Adding the thermal contribution of about $110 \mathrm{~mm}$ over next 100 years, we obtain a total sea level rise of just about $230 \mathrm{~mm}$ or $23 \mathrm{~cm}$ by 2100 (Khandekar 2009).

\section{Observed sea level variations at selected locations}

Here we present examples of observed sea level variations in a few selected locations. These locations have been well-publicized in the present climate change debate as being threatened by escalating sea levels and flooding. Among the locations most often discussed in the media and also in scientific community: 1. The Maldives 2. Tuvalu \& Vanuatu islands in the south Pacific and 3. Bangladesh and the Bay of Bengal region. Let us look at each of these three locations and assess the sea level change situation.

- The Maldives: These group of islands (about 1200 or more) in the equatorial Indian Ocean $\left(\sim 2-5^{0} \mathrm{~N}, 72-74^{0} \mathrm{E}\right)$, about $1000 \mathrm{~km}$ southwest from the southern tip of India, have become an icon in the current debate on escalating sea level rise and the Islands disappearing in the next few decades. The question of sea level rise in the Maldives has been extensively studied by Prof N-A Morner of the University of Stockholm Sweden, who was the President of the INQUA Commission for Sea Level Changes \& Coastal Evolution. Morner \& his associates have prepared a number of reports on sea level changes and the morphology of these islands (Morner 2004a,b; 2007). Morner's findings on sea level changes and morphology of the Maldives can be summarized as: The Maldives lie right in the centre of the earth's deepest geoid depression of about $-100 \mathrm{~m}$. Sea level records on the islands show several rapid oscillations, due to local and regional factors, which are not linked to global sea level changes. The people of Maldives survived a higher sea level about 800 to $1000 \mathrm{yr} \mathrm{BP}$, when the sea level was estimated to be about 50-60 cm higher than present. In the 1970s the sea level there fell by 20-30 cm, probably from an increased evaporation linked to Monsoon circulation changes. In the equatorial Indian Ocean, the dynamic sea level is significantly lowered with respect to the geoid by strong regional evaporation. Many other sharp spikes in sea level are linked to dynamic changes in sea level there with ocean circulation playing 
a significant role in combination with changes in air pressure, evaporation, precipitation etc.. The sea level at the Maldives is NOT affected by global sea level changes.

- Tuvalu and Vanuatu islands: These two islands are located in the south Pacific about $1000 \mathrm{~km}$ north \& west of the Fiji Islands. These islands have become iconic in the global warming debate with the people of Tuvalu threatening a legal action against the USA for "ongoing flooding on the island", while the small community living on the island of Vanuatu are often being identified as "The first climate change refugees" because of possibility of the island being submerged in a few years. (Vanuatu New Port Villa Press Online, December 21 2005). The sea level changes at Tuvalu and Vanuatu are shown in Figure 7. The Tuvalu record extends from 1978 to 2007, while the Vanuatu sea level tide-gauge covers the period 1993-2006. Both these records show no significant changes in recent years. The Tuvalu record shows irregular oscillations, with two of the lowest values (in early 1983 and early 1998) coinciding with the strong El Nino events of 1982/83 and 1997/98. It is widely recognized now that major El Nino events can produce significant changes in sea levels over the entire equatorial Pacific Basin from the Indonesian Archipelago in the east to Ecuador on the west coast of South America. The record at Vanuatu does not show any El Nino signature as the Vanuatu island is slightly south of $15^{0}$ latitude, where El Ninoinduced sea level changes are expected to be minimal. Besides El Nino-induced changes, the two records do not show any increasing or decreasing trend which can be linked to global warming or climate change.

The tide gauge record of Tuvalu 1978-2007

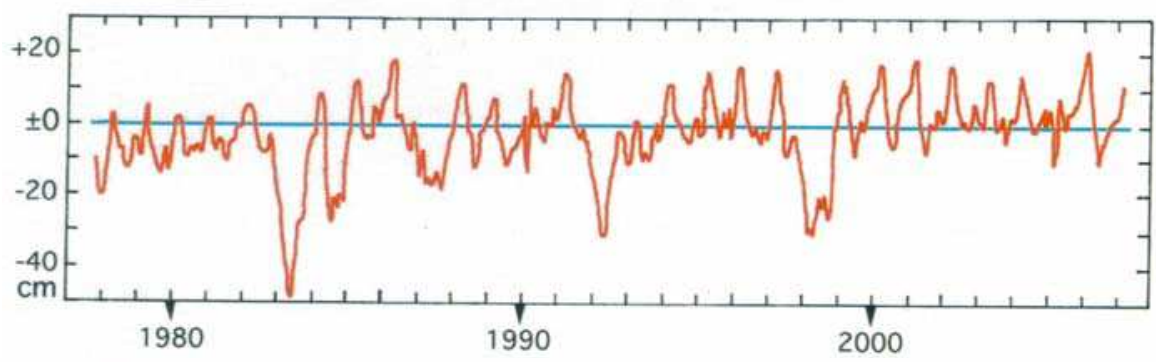

VANUATU

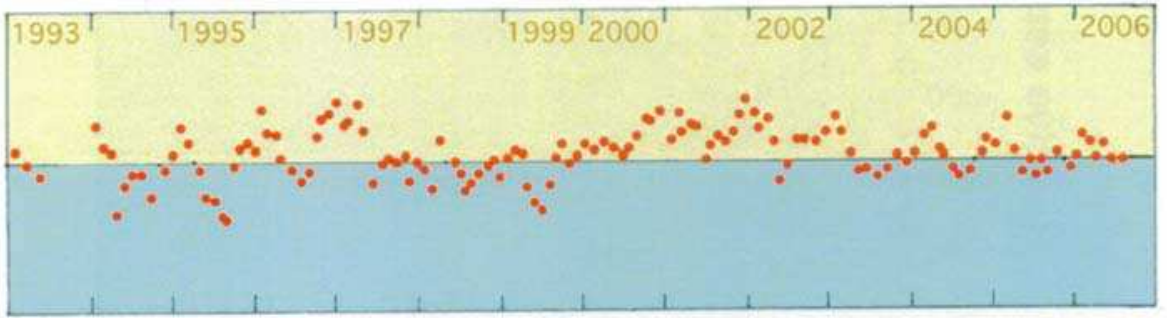

Fig. 7. Sea level records for the two south Pacific islands, Tuvalu and Vanuatu

- Bangladesh \& the adjacent area of Bay of Bengal: Bangladesh is one of the most densely populated countries with a total present population of about 140 million, in a land area of just about $144000 \mathrm{~km}^{2}$ A significant percentage of its population lives in the 
Ganges River (Holy River Ganga worshipped in India) Delta, known as the Sundarbans, the world's largest marsh area. The Delta region is only a few $\mathrm{m}$ above the sea level and is subject to frequent flooding during the summer monsoon season and also when tropical cyclones from the Bay of Bengal hit the Delta region. The storm surges generated by tropical cyclones have killed hundreds of thousands of people over last four centuries (Murty and Neralla 1996). In recent times, an intense tropical cyclone struck the Delta region on November 13 1970, killing an estimated 200,000 thousand people, largest fatalities in a single weather-related disaster! There are no long-term tide gauge data available in the Delta region. The most recent paper by Morner (2010), analyzes sea level change over the Delta using two sea level records from nearby India, one at Visakhapatnam on east coast of India and the other at Mumbai on the west coast. The sea level changes at these two locations are shown in Figure 8. The Figure shows locations of Mumbai and Visakhapatnam in conjunction with Kotka, a location in the Delta region where Morner's latest study analyzes sea level changes. Based on a careful assessment of sea level changes in the Bay of Bengal region, Morner concludes that there is NO global sea level rise signature in the Delta region of Bangladesh at this point in time. Flooding during the Monsoon season and associated river flooding remains a major problem. However, sea level rise is not a major problem for the Sundarbans region of Bangladesh today.

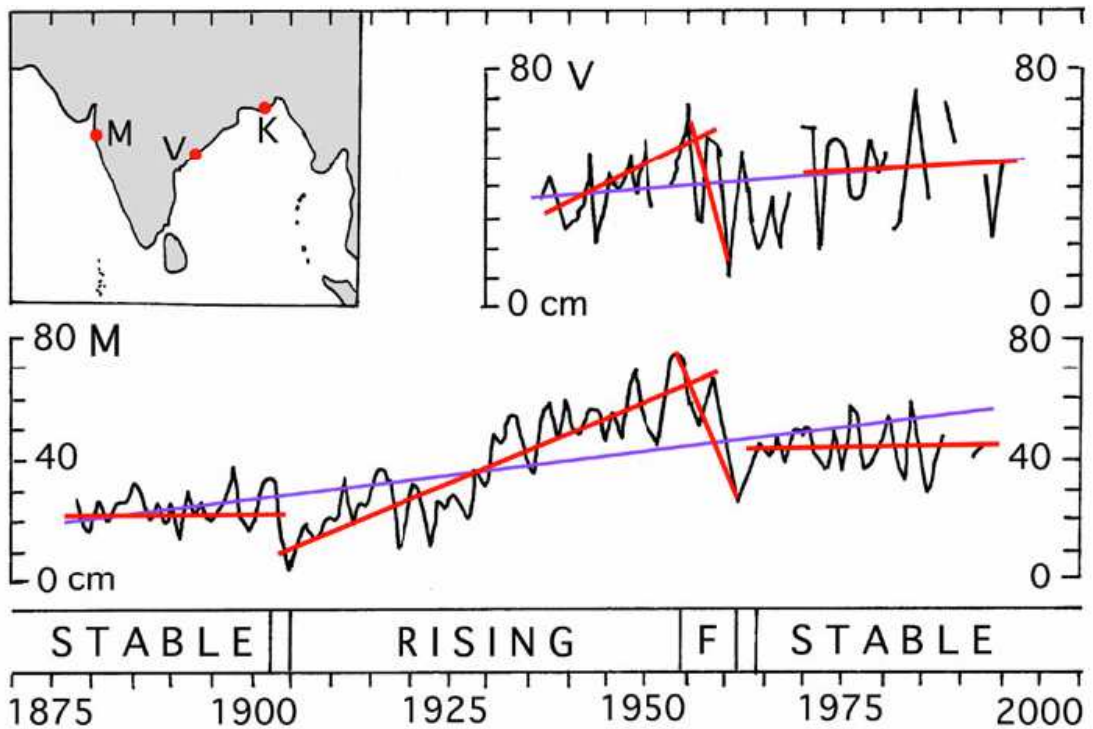

Fig. 8. Sea level trends at Mumbai (M) and Visakhapatnam (V). K denotes a location in the Sundarbans region of Bangladesh where sea level changes are analyzed (Morner 2010).

\section{Concluding remarks}

The present debate on global warming, climate change and glacier melt has highlighted the possibility of escalated sea level rise in the next few decades. A careful analysis of latest studies suggests that since about 2007, global sea level rise is estimated as between 2.3 to $2.8 \mathrm{~mm} / \mathrm{yr}$. A climatological analysis of past sea level changes in the twentieth century allows an estimate for 
future sea level rise over the next 100 years of about $23 \mathrm{~cm}+/-5 \mathrm{~cm}$ with a $95 \%$ confidence. In view of declining global SSTs and possible continued cooling of the earth's mean temperature over the next decade (Keenlyside et al 2008), the best guess value for sea level rise from now until 2025 is estimated to be just about $30 \mathrm{~mm}+/-10 \mathrm{~mm}$. This value appears modest and does not pose a major threat to some of the most vulnerable areas of the world like the Maldives, Bangladesh and the south Pacific islands of Tuvalu and Vanuatu.

\section{Acknowledgements}

It is a pleasure to acknowledge useful communications with Prof Morner of the University of Stockholm, Sweden. Thanks are also due to my wife Shalan for her technical help in reproducing the Figures used in this Chapter.

\section{References}

Arun Kumar et al 2001: The sustained North American warming of 1997 \& 1998. Journal of Climate, $14, p .345-353$

Chylek P, M K Dubey \& G Lesins 2006: Greenland warming of 1920-1930 and 1995-2005. Geophysical Research Letters 33 L11707 doi:10.1029/2006GL026510

Chylek P, M K Dubey \& U Lohmann 2008: Aerosol radiative forcing and climate sensitivity deduced from the Last Glacial Maximum to Holocene transition. Geophysical Research Letters 35 L04804 doi;10.1029/2007GL02759

Bahr D B, M Dyurgerov \& M Meier 2009: Sea-level rise from glaciers and ice caps: A lower bound. Geophysical Research Letters 36 L030501 doi:10.1029/2008GL036309

Cazenave Anny 2006: How fast are the ice sheets melting? Science 314 p.1250-1252

Cazenave Anny et al 2008: Sea level budget over 2003-2008: A reevaluation from GRACE space gravimetry, satellite altimetry and Argo. Global \& Planetary Change, doi:10.1016/j.gloplacha.2008.10.004

Douglas B C and W R Peltier 2002: The puzzle of global sea level rise. Physics Today March 2002 p. 35-40 American Institute of Physics USA

Flemming K et al 1998: Refining the eustatic sea level curve since the Last Glacial Maximum using far- and intermediate-field sites. Earth and Planetary Science Letters 163 p.327-342

Holgate S J 2007: On the decadal rates of sea level changes during the twentieth century. Geophysical Research Letters 34 L01602 doi:10.1029/2006GL028492

Holgate S J and P L Woodworth 2004: Evidence for enhanced sea level rise during the 1990s. Geophysical Research Letters 31 L07305 doi:10.1029/2004GL019626

Jevrejeva $S$ et al 2006: Nonlinear trends and multiyear cycles in sea level records. Journal of Geophysical Research 111 C09012 doi:10.1029/2005JC003229

Keenlyside N S et al 2008: Advancing decadal-scale climate prediction in the North Atlantic sector. Nature 453 p.84-88 doi:10.1038/nature06921

Khandekar M L, T S Murty \& P Chittibabu 2005: The global warming debate: A review of the state of science. Pure \& Applied Geophysics 162 p. 1557-1586.

Khandekar M L, 2009: Global warming and sea level rise. Energy \& Environment 20 p. 1067-1074

Knutti $\mathrm{R}$ et al 2008: A review of uncertainties in global temperature projections over the twenty-first century. Journal of Climate 21 p.2651-2663

Lambeck K 2002: Sea-level changes from mid-Holocene to recent times: An Australian example with global implications. Ice Sheets, Sea Level and the Dynamic earth, Mitrovica E Vermeersen (Eds), Geodynamic Series, Vol 29 p. 33-50 
Lindzen R S 2007: Taking global warming seriously. Energy \& Environment 18 p. 937-950

Meehl G A (plus 80 other auhors) 2007: Global Climate Projections. Climate Change 2007: The Physical Science Basis-Contribution of Working Group I to the Fourth Assessment Report of the Intergovernmental Panel on Climate Change (IPCC), S Solomon et al (eds) p. 748845 Cambridge University Press

Meier M et al 2007: Glaciers dominate eustatic sea-level rise in the $21^{\text {st }}$ century. Science 317 p.1064-1067.

Mitrovica J X, N Gomez \& P Clark 2009: The sea-level fingerprint of west Antarctic collapse. Science 323 p.753

Morner N-C 2004a: New perspectives for the future of the Maldives. Global \& Planetary Change 40 p.177-182

Morner N-C 2004b:Sea level changes: Are low-lying areas and coastal areas under threat? The impact of climate change: an appraisal for future p.29-35 International Policy Press UK

Morner N-C 2007: Sea level changes and tsunamis. Environmental stress and migration over the seas. Internationales Asienforum 38 p.353-374

Morner N-C 2010: Sea level changes in Bangladesh: new observational facts. Energy $\mathcal{E}$ Environment 21 p. 235-249.

Munk W 2002: Twentieth century sea level: An enigma. Proc. Of the National Academy of Sciences (USA) V 99 p. 6550-6565

Munk W 2003: Ocean freshening, sea-level rising. Science 300, p.2041-2043.

Murty T S and V R Neralla 1996: El-Nino and storm surges in the Bay of Bengal. Land-based and marine hazards M I El-Sabh et al (eds) Kluwer Pub. p. 97-111

Paulson A, S Zhong \& J Wahr 2007; Inference on mantle viscosity from GRACE and relative sea level data. Geophysical Journal International 171 p.497-508

Peltier W R 2009: Closure of the budget of global sea level rise over GRACE era: the importance and magnitude of the required corrections for global isostatic adjustment. Quaternary Science Reviews 28 p. 1658-1674

Peltier W R 1996: Global sea level rise and glacial isostatic adjustment: an analysis of data from the east coast of America. Geophysical Research Letters 23 p.717-720

Peltier W R 1998: Postglacial variations in the level of sea: implications for climate dynamics and earth geophysics. Reviews of Geophysics 36 p.603-689

Peltier W R 2001: Global glacial isostatic adjustment and modern instrumental records of relative sea level history. Sea Level Rise: History \& Consequences. B C Douglas M Kearney $\mathcal{E} S$ Leatherman (eds) Academic Press. International Geophysical Series Volume 75 p. 65-95

Peltier W R and R Drummond 2008: Rheological stratification of the lithosphere:a direct reference upon the geodetically observed pattern of the glacial isostatic adjustment of the North American continent. Geophysical Research Letters, 35,L16314 doi:10.1029/2008GL034586

Revelle R and H E Suess 1958: Carbon dioxide exchange between atmosphere and ocean and the question of an increase of atmospheric $\mathrm{CO}_{2}$ during the past decades. Tellus $9 p$. 18-27

Schwartz S E 2007: Heat capacity, time constant and sensitivity of earth's climate system. Journal of Geophysical Research 112 D24S05 doi;10.1029/2007JD008746

Wunsch C, R M Ponte and P Heimbach 2007: Decadal trends in sea level patterns:1993-2004. Journal of Climate, 20, p.5889-5911 


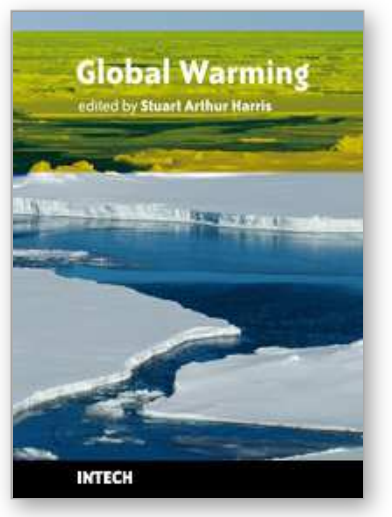

\author{
Global Warming \\ Edited by Stuart Arthur Harris
}

ISBN 978-953-307-149-7

Hard cover, 250 pages

Publisher Sciyo

Published online 27, September, 2010

Published in print edition September, 2010

This book is intended to introduce the reader to examples of the range of practical problems posed by "Global Warming". It includes 11 chapters split into 5 sections. Section 1 outlines the recent changes in the Indian Monsoon, the importance of greenhouse gases to life, and the relative importance of changes in solar radiation in causing the changes. Section 2 discusses the changes to natural hazards such as floods, retreating glaciers and potential sea level changes. Section 3 examines planning cities and transportation systems in the light of the changes, while section 4 looks at alternative energy sources. Section 5 estimates the changes to the carbon pool in the alpine meadows of the Qinghai-Tibet Plateau. The 11 authors come from 9 different countries, so the examples are taken from a truly international set of problems.

\title{
How to reference
}

In order to correctly reference this scholarly work, feel free to copy and paste the following:

Madhav Khandekar (2010). Global Warming, Glacier Melt \& Sea Level Rise: New Perspectives, Global Warming, Stuart Arthur Harris (Ed.), ISBN: 978-953-307-149-7, InTech, Available from:

http://www.intechopen.com/books/global-warming/global-warming-glacier-melt-sea-level-rise-new-perspectives

\section{INTECH}

open science | open minds

\section{InTech Europe}

University Campus STeP Ri Slavka Krautzeka 83/A 51000 Rijeka, Croatia Phone: +385 (51) 770447 Fax: +385 (51) 686166 www.intechopen.com

\section{InTech China}

Unit 405, Office Block, Hotel Equatorial Shanghai No.65, Yan An Road (West), Shanghai, 200040, China 中国上海市延安西路65号上海国际贵都大饭店办公楼405单元 Phone: +86-21-62489820

Fax: +86-21-62489821 
(C) 2010 The Author(s). Licensee IntechOpen. This chapter is distributed under the terms of the Creative Commons Attribution-NonCommercialShareAlike-3.0 License, which permits use, distribution and reproduction for non-commercial purposes, provided the original is properly cited and derivative works building on this content are distributed under the same license. 